\title{
Moyamoya-like cerebrovascular disease in a child with a novel mutation in myosin heavy chain 11
}

Annette Keylock, MSc, Ying Hong, PhD, Dawn Saunders, MD, Ebun Omoyinmi, PhD, Ciara Mulhern, MSc, Derek Roebuck, MD, Paul Brogan, PhD, Vijeya Ganesan, MD,* and Despina Eleftheriou, PhD*

Neurology ${ }^{\circledR}$ 2018;90:136-138. doi:10.1212/WNL.0000000000004828

Heterozygous mutations in the MYH11 gene affecting the C-terminal coiled-coil region of the smooth muscle myosin heavy chain, a contractile protein of smooth muscle cells (SMC), have been described to cause thoracic aortic aneurysm or aortic dissection (TAAD) and patent ductus arteriosus (PDA). ${ }^{1}$ Herein we expand the phenotype associated with MYH11 mutations to include moyamoya-like cerebrovascular disease.

\section{Case report}

A 2-year-old girl of Moroccan nonconsanguineous descent presented with a right-sided hemiparesis and aphasia (figure e-1, links.lww.com/WNL/A36). Brain MRI revealed an acute left anterior and middle cerebral artery territory (ACA/MCA) infarct and prior infarction in the right ACA/MCA territory (figure e-1). The clinical correlate of the latter was an episode of reluctance to use the left hand. Catheter angiography showed bilateral stenosis of the terminal internal carotid artery (TICA)/middle cerebral artery with a collateralization pattern consistent with moyamoya arteriopathy (figure 1, A-F). Visceral digital subtraction angiography revealed narrowing of the mid-aorta and bilateral renal artery stenosis (figure 1G). Echocardiography showed a small PDA. In view of 2 cutaneous café-au-lait spots, genetic screening for neurofibromatosis type 1 was undertaken and was negative; array comparative genomic hybridization was normal. She had no mydriasis, gastrointestinal, bladder, or bowel dysfunction. She was considered to have a generalized vasculopathy with prominent cerebral involvement and she underwent bilateral pial synangiosis. There was radiologic arteriopathy progression over 4 years, with new right frontal infarction, increased stenosis of the right internal carotid artery/ MCA, and occlusion of the left TICA with the development of more basal collaterals (figure 1, $\mathrm{D}-\mathrm{F}$, and figure e-1). She currently has residual asymmetric tetraparesis with pseudobulbar features and is normotensive with normal cardiac function.

Whole exome sequencing (Methods appendix e-1, links.lww.com/WNL/A38) revealed a novel heterozygous missense mutation in MYH11 gene NM_002474:c.4604G>A (p.R1535Q) confirmed with Sanger sequencing (figure $1 \mathrm{H}$ ) present in both the proband and her father and predicted damaging based on SIFT, MutationTaster, and PolyPhen-2 programs. This finding also had implications for the proband's father, for whom annual cardiovascular monitoring was initiated; baseline cardiac MRI and magnetic resonance angiography were normal for him.

To date, a number of vascular disorders have been associated with mutations directly affecting SMC contractile proteins or proteins that disrupt SMC contractility (table e-1, links.lww.com/WNL/A37). ${ }^{2}$ The majority of these conditions are characterized by prominent thoracic aorta involvement. ${ }^{1-3}$ Recently, however, specific mutations, for instance heterozygous missense mutations in ACTA2 disrupting Arg179, have been shown to

\author{
Correspondence \\ Dr. Eleftheriou \\ d.eleftheriou@ucl.ac.uk
}



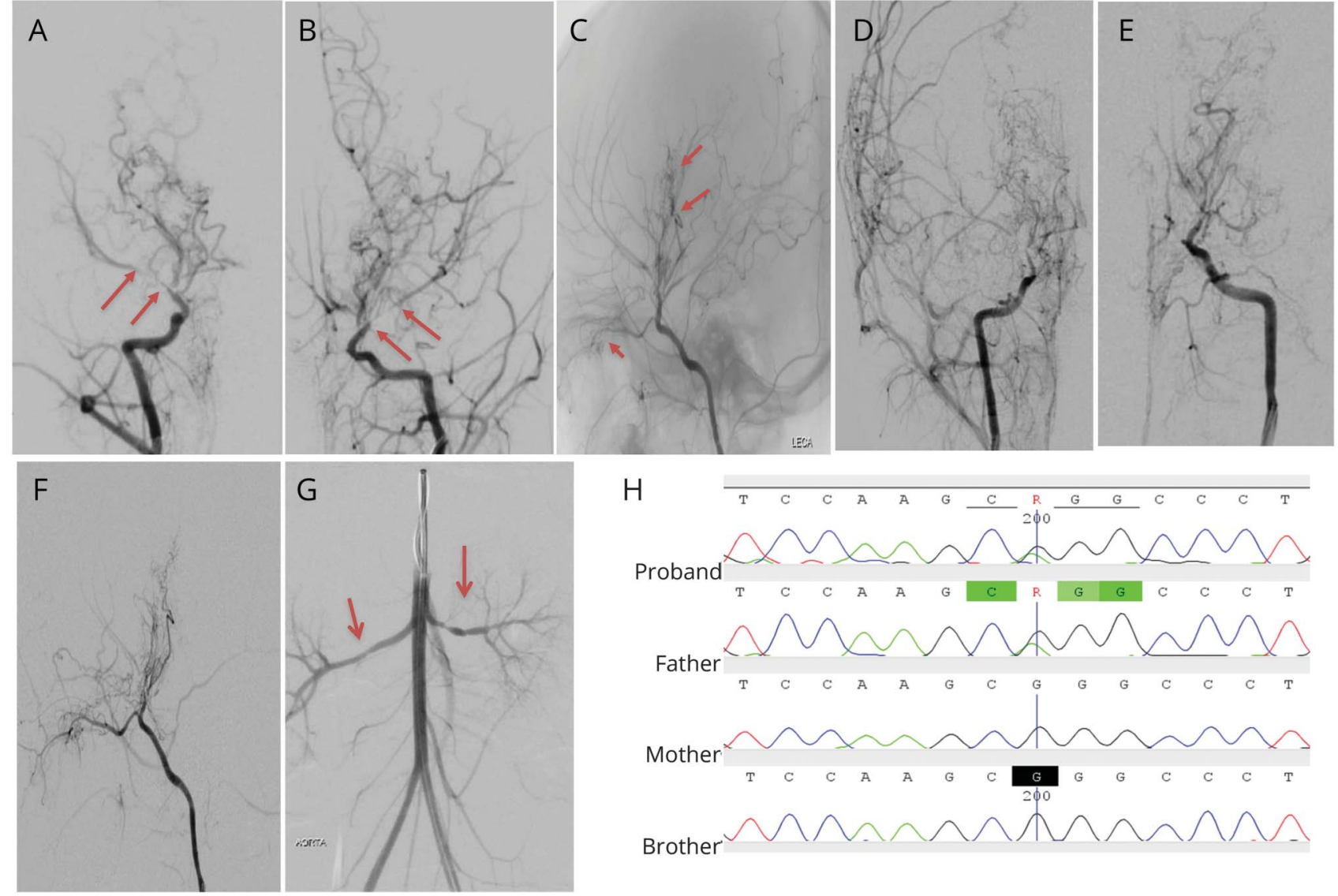

$\mathrm{H}$

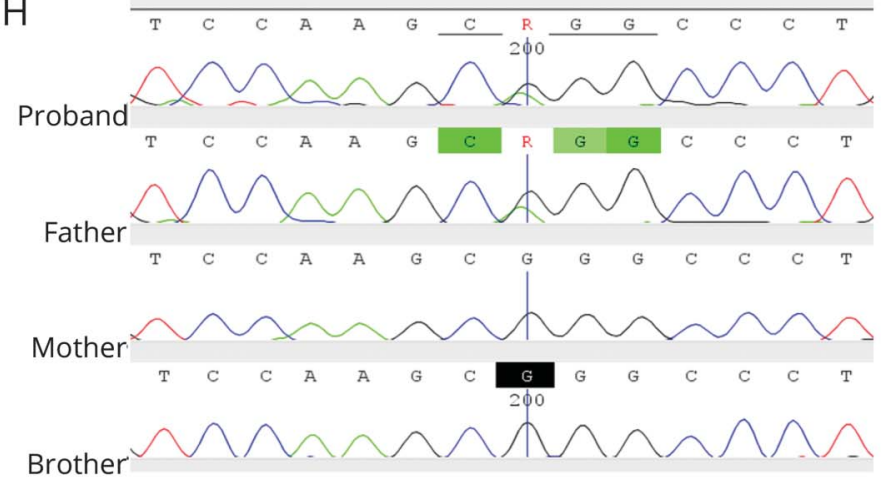

(A) Right and (B) left anteroposterior projections of the internal carotid artery (ICA) injections of the cerebral angiogram at presentation demonstrate narrowing of the terminal internal carotid artery (TICA) and straight and long segment narrowing of the M1 and A1 segments of the middle cerebral artery (MCA) (between arrows) and anterior cerebral artery (ACA) bilaterally. Moyamoya collaterals are present on the initial angiogram. (C) Lateral projection of the left ICA injection demonstrates the presence of basal and moyamoya collaterals (short arrows). Four years later, progression of the arteriopathy is seen with (D) further narrowing of the right M1 segment of the MCA and (E, F) occlusion of the left TICA with absent filling of the terminal ACA and MCA arteries. (F) The number of basal and moyamoya collaterals has increased. The pial collaterals in (C) are a result of the pial synangiosis. (G) Bilateral narrowing of the renal arteries seen on digital subtraction renal angiography. $(\mathrm{H})$ Sanger sequencing chromatogram of MYH11 gene aligned to reference sequence exon 33 of $M Y H 11$ (NM_002474). Line indicates a heterozygous nonsynonymous substitution present in the proband and father c.4604G>A (p.R1535Q) but not in the mother or brother.

associate mainly with cerebrovascular disease. ${ }^{4}$ We now also expand the phenotype associated with heterozygous mutations in MYH11 to include an occlusive cerebral arteriopathy. We would suggest that screening for cerebrovascular involvement should be recommended for all patients with MYH11 mutations. This is also clinically relevant as $\beta$-blockade may be considered in patients with TAAD and $\beta$-blockade may adversely affect systemic blood pressure and therefore perfusion of the brain.

The radiologic phenotype of the observed arteriopathy appears to be different from that associated with ACTA2. The ACTA 2 arteriopathy is characterized by an abnormally straight morphology of proximal branches of the circle of Willis, occlusive features, and a paucity of basal collaterals, distinct from classical "moyamoya." 4,5 The initial arterial morphology in the MYH11 patient also shows this straight configuration of the arterial circulation although, in contrast to ACTA2 patients, the index cases go on to develop profuse basal "moyamoya" collaterals over time. While in ACTA2 patients the distinctive radiologic signature is readily apparent, ${ }^{4,5}$ it may be that other SMC-related arteriopathies have morphologic signatures that are yet to be recognized.

The missense alteration, R1535Q, in exon 33 of MYH11 that we identified is likely to affect the communication between the motor domain and the coiled-coil tail of the SM-MHC-11 protein. Similar changes in the SM-MHC-11 protein structure in TAAD lead to reduced myosin motor elasticity, aberrant interactions with actin filaments, SMC shortening, and contractile force generation followed by upregulation of tumor growth factor- $\beta$ activity. ${ }^{6,7}$ A similar mechanism may be implicated in the pathogenesis of the cerebral arteriopathy we observed with various external triggers contributing to disease development. The lack of a vascular phenotype in the father to 
date is in line with previous reports that suggested variability of disease onset and progression in relation to TAAD associated with $\mathrm{MYH} 11^{6,7}$

We emphasize the systemic nature of the vasculopathy associated with MYH11 mutations and the need for broader than previously suggested vascular surveillance to include the cerebrovascular circulation. The contribution of MYH11 mutations to isolated cerebral arteriopathy remains to be established. We would propose that MYH11 testing could be considered in children with moyamoya who have atypical features on cerebral angiography or poor response to pial synangiosis.

\section{Author contributions}

Annette Keylock: data analysis, whole exome sequencing, Sanger sequencing, writing of manuscript. Ying Hong: Sanger sequencing, data analysis, writing of the manuscript. Ciara Mulhern: data analysis and review of manuscript. Ebun Omoyinmi: data analysis and review of manuscript. Dawn Saunders: imaging data collection, writing of the manuscript. Derek Roebuck: imaging data collection, review of the manuscript. Paul Brogan: design of the study, data collection and analysis, writing of the manuscript. Vijeya Ganesan: data collection and analysis, writing of the manuscript. Despina Eleftheriou: design of the study, data acquisition, analysis, writing and final approval of the manuscript.

\section{Study funding}

Annette Keylock is supported by a British Heart Foundation grant. Ying Hong and Ebun Omoyinmi are supported by Rosetrees Trust. Ciara Mulhern is supported by GOSH Children's Charity grant. Despina Eleftheriou is supported by Arthritis Research UK (grant 20164). The study was supported by a British Heart Foundation PhD studentship grant.

\section{Disclosure}

A. Keylock is supported by the British Heart Foundation. Y. Hong is supported by Rosetrees Trust. D. Saunders reports no disclosures relevant to the manuscript. E. Omoyinmi is supported by Rosetrees Trust. C. Mulhern is supported by GOSH Children's Charity grant. D. Roebuck reports no disclosures relevant to the manuscript. P. Brogan has received institutional grants from Sobi, Novartis, and Roche and consultancy fees from Roche and Sobi. V. Ganesan is receiving research support from NIHR. D. Eleftheriou is receiving research support from ARUK and has received institutional grants from Roche and Lilly. Got to Neurology. org/N for full disclosures.

Received April 2, 2017. Accepted in final form October 10, 2017.

\section{References}

1. Zhu L, Vranckx R, Khau Van Kien P, et al. Mutations in myosin heavy chain 11 cause a syndrome associating thoracic aortic aneurysm/aortic dissection and patent ductus arteriosus. Nat Genet 2006;38:343-349.

2. Milewicz DM, Guo DC, Tran-Fadulu V, et al. Genetic basis of thoracic aortic aneurysms and dissections: focus on smooth muscle cell contractile dysfunction. Annu Rev Genomics Hum Genet 2008;9:283-302.

3. Guo DC, Pannu H, Tran-Fadulu V, et al. Mutations in smooth muscle alpha-actin (ACTA2) lead to thoracic aortic aneurysms and dissections. Nat Genet 2007;39: $1488-1493$.

4. Munot P, Saunders DE, Milewicz DM, et al. A novel distinctive cerebrovascular phenotype is associated with heterozygous Arg179 ACTA2 mutations. Brain 2012; 135:2506-2514.

5. Starosolski Z, Villamizar CA, Rendon D, et al. Ultra high-resolution in vivo computed tomography imaging of mouse cerebrovasculature using a long circulating blood pool contrast agent. Sci Rep 2015;5:10178.

6. Pannu H, Tran-Fadulu V, Papke CL, et al. MYH11 mutations result in a distinct vascular pathology driven by insulin-like growth factor 1 and angiotensin II. Hum Mol Genet 2007;16:2453-2462.

7. Renard M, Callewaert B, Baetens M, et al. Novel MYH11 and ACTA2 mutations reveal a role for enhanced TGF $\beta$ signaling in FTAAD. Int J Cardiol 2013;165: 314-321. 


\section{Neurology}

\section{Moyamoya-like cerebrovascular disease in a child with a novel mutation in myosin heavy chain 11}

Annette Keylock, Ying Hong, Dawn Saunders, et al. Neurology 2018;90;136-138 Published Online before print December 20, 2017

DOI 10.1212/WNL.0000000000004828

\section{This information is current as of December 20, 2017}

\section{Updated Information \&} Services

References

Subspecialty Collections

Permissions \& Licensing

Reprints including high resolution figures, can be found at: http://n.neurology.org/content/90/3/136.full

This article cites 7 articles, 0 of which you can access for free at: http://n.neurology.org/content/90/3/136.full\#ref-list-1

This article, along with others on similar topics, appears in the following collection(s):

All Cerebrovascular disease/Stroke

http://n.neurology.org/cgi/collection/all_cerebrovascular_disease_strok e

All Genetics

http://n.neurology.org/cgi/collection/all_genetics

All Pediatric

http://n.neurology.org/cgi/collection/all_pediatric

Childhood stroke

http://n.neurology.org/cgi/collection/childhood_stroke

Pediatric stroke; see Cerebrovascular Disease/ Childhood stroke $\mathrm{http}: / /$ n.neurology.org/cgi/collection/pediatric_stroke_see_cerebrovascu lar_disease-childhood_stroke

Information about reproducing this article in parts (figures,tables) or in its entirety can be found online at:

http://www.neurology.org/about/about_the_journal\#permissions

Information about ordering reprints can be found online:

http://n.neurology.org/subscribers/advertise

Neurology ${ }^{\circledR}$ is the official journal of the American Academy of Neurology. Published continuously since 1951, it is now a weekly with 48 issues per year. Copyright Copyright (C) 2017 The Author(s). Published by Wolters Kluwer Health, Inc. on behalf of the American Academy of Neurology.. All rights reserved. Print ISSN: 0028-3878. Online ISSN: 1526-632X.

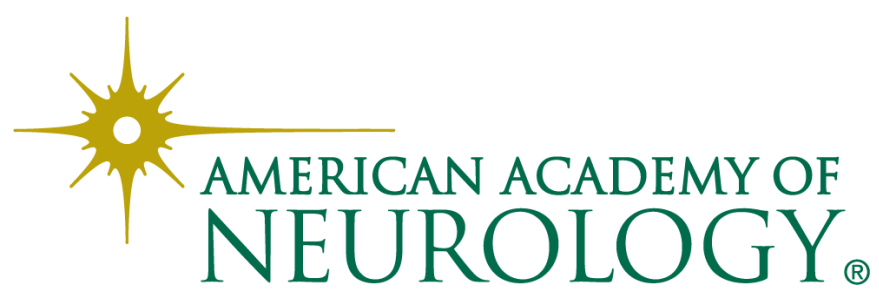

